\title{
A Literary-Rhetorical Analysis of Psalm 93 for Translation and Performance in isiZulu
}

\author{
JUNE DiCKIE (UNIVERSITY OF KWA-ZULU NATAL)
}

\begin{abstract}
The proposition underlying this research is that interested isiZuluspeakers could use a systematic methodology to translate selected praise psalms in a poetically-beautiful and rhetorically-powerful way. The methodology has three elements: first the poetic features in the Hebrew text (and their functions) are analysed, using the literaryrhetorical approach of Wendland. Second, for an empirical study, isiZulu-speakers interested in poetry are invited to participate in a workshop to learn the basics of Bible-translation and typical features of Zulu poetry and music. They then compose their own translations of some praise psalms (using Zulu poetic features achieving a similar function to those in the source text) and perform their poems as songs or spoken-poetry items. Third, the success of the exercise is evaluated on the basis of functional translation, using the traditional criteria of accuracy, naturalness, and clarity, as well as the additional criteria of artistry, aurality, and acceptability.
\end{abstract}

KEY WORDS: poetic features; Bible translation; praise psalms; functional translation.

\section{A INTRODUCTION}

The translation of poetry is often difficult for the average local Bible-translator in the field. This paper proposes a systematic methodology with three characteristics: first, it uses Ernst Wendland's literary-rhetorical approach to analyse the Hebrew poetic text; second, it includes an empirical study with local (Zulu) youth both translating and performing the text in their mother-tongue; and third, the resulting translations are evaluated using the traditional criteria of accuracy, naturalness, and clarity as well as three additional criteria suggested by Wendland as being appropriate for literary-rhetorical translations (viz. artistry, aurality, and acceptability).

The first step in the methodology is treated in section B where Wendland's approach is applied to Ps 93, the example chosen for this paper. Section $\mathrm{C}$ gives a brief description of the second step in the methodology, the

* Article submitted: 4/02/2017; peer-reviewed: 17/03/2017; accepted: 22/03/2017. To cite: June Dickie, "A Literary-Rhetorical Analysis of Psalm 93 for Translation and Performance in isiZulu," Old Testament Essays 30/1 (2017): 77-102. Doi: http:// dx.doi.org/10.17159/2312-3621/2017/v30n1a6 
empirical study. And the third step, the assessment of the empirical translations, is treated in section D.

\section{B LITERARY-RHETORICAL ANALYSIS OF HEBREW TEXT}

The steps advocated by Wendland are applied to Ps 93:

\section{Consider the Original Context of the Text}

Psalm 93 presented an important message in the original context of the apparent failure of the Davidic covenant (indicated in Ps 89). As noted by many scholars (e.g. Bullock ${ }^{1}$ and Bellinger ${ }^{2}$ ), this psalm is part of a group (usually delineated from Ps 90 to Ps 106) dealing with the "Kingship of YHWH" (including his kingship over creation) which is the reason to give him praise. Despite the circumstances which may seem to indicate otherwise, YHWH still reigns. This message, of "the reign of God with its stability and trustworthy decrees" was "both difficult and essential" in the ancient context, as it is today. ${ }^{3}$

Some form critics ${ }^{4}$ call these psalms "enthronement psalms" and suggest that the Israelites celebrated YHWH's re-enthronement at an annual harvest festival. ${ }^{5}$ Not all scholars (e.g. Bullock ${ }^{6}$ ) accept that the Israelites performed such a ritual, but it is probable that the psalm was linked to the Jerusalem Temple. ${ }^{7}$ In its cultic role, it seems that Ps 93 was part of the weekly liturgy, sung after the morning and afternoon sacrifices on the sixth day of the week. ${ }^{8}$

The psalm celebrates the victory of YHWH over all other gods, including the sea-monsters (symbolising chaos). ${ }^{9}$ By his victory, holiness is restored to the temple, blessings follow, ${ }^{10}$ and YHWH's people can rejoice and know true

1 Hassel C. Bullock, Encountering the Book of Psalms (Grand Rapids: Baker, 2001), 188.

2 William H. Bellinger, Jr., Psalms: Reading and Studying the Book of Praises (Massachusetts: Hendrikson, 1990), 87.

3 Walter Brueggemann and William H. Bellinger, Psalms (New York: CUP, 2014), 404.

4 E.g. Sigmund O. P. Mowinckel, The Psalms in Israel's Worship (Oxford: Basil Blackwell, 1982), 106.

5 Marvin Tate, Psalms 51-100 (Dallas: Word Books, 1990).

6 Bullock, Encountering, 188.

7 Frank-Lothar Hossfeld and Erich Zenger, Psalms, vol. 2 (Minneapolis: Fortress Press, 2005), 447.

8 See Alexander F. Kirkpatrick, The Book of Psalms (Cambridge: CUP, 1902), 563. Also Bullock, Encountering, 92 and m. Sukkah 4:9, 10).

9 Mowinckel, Psalms, 183.

10 Mowinckel, Psalms, 164. 
security. The psalm calls upon the community to praise the God who comes to deliver and who is present to bless. ${ }^{11}$

\section{Consider the Boundaries of the Text}

It is important to recognise that the position of a psalm within a larger group is an essential part of understanding its full meaning. Zakovitch ${ }^{12}$ notes: "Rabbinic literature dedicates much attention to the purpose of the juxtapositions of literary units in the Bible." Rabbinic literature reflects a very ancient tradition, and the fact that from early times it was considered important to study the literary context of biblical text underlines the relevance for us to do the same.

Various scholars assert the close relationship between Ps 93 and the psalms on either side of it (92 and 94-95) ${ }^{13}$ which in turn relate to the psalms on either side of them, creating a group from Ps $92 / 93$ to Ps $99 / 100,{ }^{14}$ which McCann ${ }^{15}$ considers "the theological heart of the Psalter." In this group, the nations are seen to be "drawing closer and closer to Israel and its God."16 Psalm 93 provides a thematic link between two sub-groups (Pss 92-95 and Pss 96-99) having the "YHWH reigns" formula. ${ }^{17}$

\section{Do a Text-Critical Analysis}

The LXX gives a title to Ps 93: "For the day before the Sabbath, when the land had been filled with inhabitants." This title is supported by Talmudic tradition, ${ }^{18}$ and links the psalm to Ps $92 .{ }^{19}$

11 Bellinger, Psalms, 92.

12 Yair Zakovitch, "The Interpretive Significance of the Sequence of Psalms," in The Composition of the Book of Psalms, ed. Erich Zenger (Leuven: Uitgeverij Peeters, 2010), 215.

13 David M. Howard, "Recent Trends in Psalms Study," in The Face of Old Testament Studies, ed. David W. Baker and Bill T. Arnold (Grand Rapids: Baker Books, 1999), 89 links Ps 93 to Ps 92 as do Hossfeld and Zenger, Psalms 2, 449-450. Several close semantic links between Ps 93 and Ps 94 are also noted by Hossfeld and Zenger, Psalms 2, 449-450.

14 Scholars differ as to the boundaries of this group. Generally, the "YHWH is king" group (the literary composition) is considered to be Pss 93 to 100. The original liturgical composition is thought to be Pss 93, 95, 96, 98, and 100.

15 J. Clinton McCann, The Shape and Shaping of the Psalter, JSOTSup 159 (Sheffield: JSOT Press, 1993).

16 Hossfeld and Zenger, Psalms 2, 497 and 450.

17 Bullock, Encountering, 190.

18 Kirkpatrick, Psalms, 563.

19 Psalm 92 has the superscription "A Psalm. For the Sabbath Day." See Hossfeld and Zenger, Psalms 2, 446. 
In v. 1d, the old manuscripts place a copula before התאָָזָר ("he has girded himself") because they see the lack of a material object for לְּ ("he is clothed"), and find it in iע ("power"). However, this alters the poetic structure of v. 1a and thus does not seem acceptable. ${ }^{20}$

In 1e, in place of niphal "(the world) is firmly fixed," the ancient versions read piel "he has firmly established the world." This finds support in the Qumran manuscript 11QPs(a). Thus many modern scholars accept this emendation, but its adoption diminishes the assonance and the MT is to be preferred.

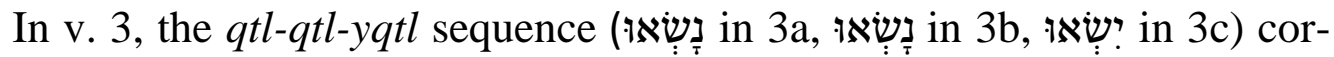
responds to Ugaritic stylistic practice, thus the proposed emendation of final imperfect ישישֶאו to a perfect verb is unlikely. ${ }^{21}$ In v. 4b, the Masoretes made "more powerful than the waves of the sea" into a parenthesis "(powerful are the waves of the sea)" but this loses the MT parallelism with v. 4a and the comparison which culminates in v. $4 \mathrm{c}$.

Briggs and Briggs ${ }^{22}$ claim that the MT version of v. 5 is an emendation to include the corresponding concepts of the Law and the temple. Dahood ${ }^{23}$ seems to agree in that he reads the first word as "your enthronement," claiming that v. 5 a "structurally balances verse 2" and thus must contain the Ugaritic root ("throne"). This could be possible, but in this study, the MT was followed, noting Bellinger's observation ${ }^{24}$ that this psalm links creation with the law.

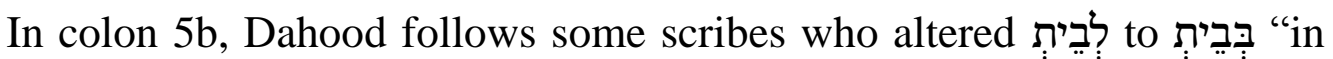
the house." Then he takes the verb as "laud," and interprets קדֶש as "the holy ones" referring to "the gods or divine beings composing YHWH's celestial council." 25 Support for this comes from a Qumran manuscript, 4QPs(b), which takes $n w h$ as a 3rd per sg. qal verb. ${ }^{26}$ Dahood claims that this "may prove to be a more satisfactory reading and grammatically more feasible." However, rhetorically vv. 3 and 4 are building to a crescendo of praise, and v. 5 is better understood as declarative praise than as a statement about "other beings." Thus the MT is preferred.

20 Hossfeld and Zenger, Psalms 2, 446 note "b."

21 Mitchell Dahood, S. J., Psalms II (51-100), AB (New York: Doubleday, 1968), 341.

22 Charles A. Briggs and Emilie G. Briggs, A Critical and Exegetical Commentary on the Book of Psalms, ICC (Edinburgh: T \& T Clark, 1960), 303.

23 Dahood, Psalms II, 339, 342, 343.

24 Bellinger, Psalms, 87.

25 For this collective meaning of קדָש , see James D. Shenkel, "The Dead Sea Psalms Scroll," Bib 46 (1965): 413.

26 The alternative is to interpret it as a piel infinitive construct, as in Ps 147:1. However, the MT interprets נָָאוזה in Ps 147:1 as a singular adjective "beautiful, seemly." 


\section{Posit the Genre and Sub-Genre}

Psalm 93 is one of 30 "psalms of praise," 27 but because it gives reasons for praise, it shows extension beyond simple praise and thus is designated "descriptive praise." ${ }^{28}$ Howard ${ }^{29}$ asserts that Pss 93-100 show the growing notion of "YHWH's kingship" within the group. Although "Kingship of YHWH" is not a formal genre per se, these psalms are linked together thematically, having the clause יהוֹה מָלָּ ("the LORD reigns") or הַמֵלָּ יִהוָה ("the LORD is/has become king"). These psalms declare not only the reality of YHWH's current reign but include, too, a picture of his future kingship (e.g. 96:12-13; 98:7-9). While an earthly king sat on the throne of Israel, the people easily forgot that he actually represented a higher king. But when the human monarchy had failed, the declaration that "The LORD reigns!" was great assurance. ${ }^{30}$

Gerstenberger $^{31}$ notes that YHWH is praised using the five kinds of statement typical of these YHWH-Kingship psalms; these are third-person affirmations about the superiority of YHWH, communal praise of YHWH (in direct address), descriptions of the behaviour of other powers, statements about the activities of the congregation, and a summons to praise (plural imperatives).

\section{Plot Repetition: ${ }^{32}$ Note Key Concepts}

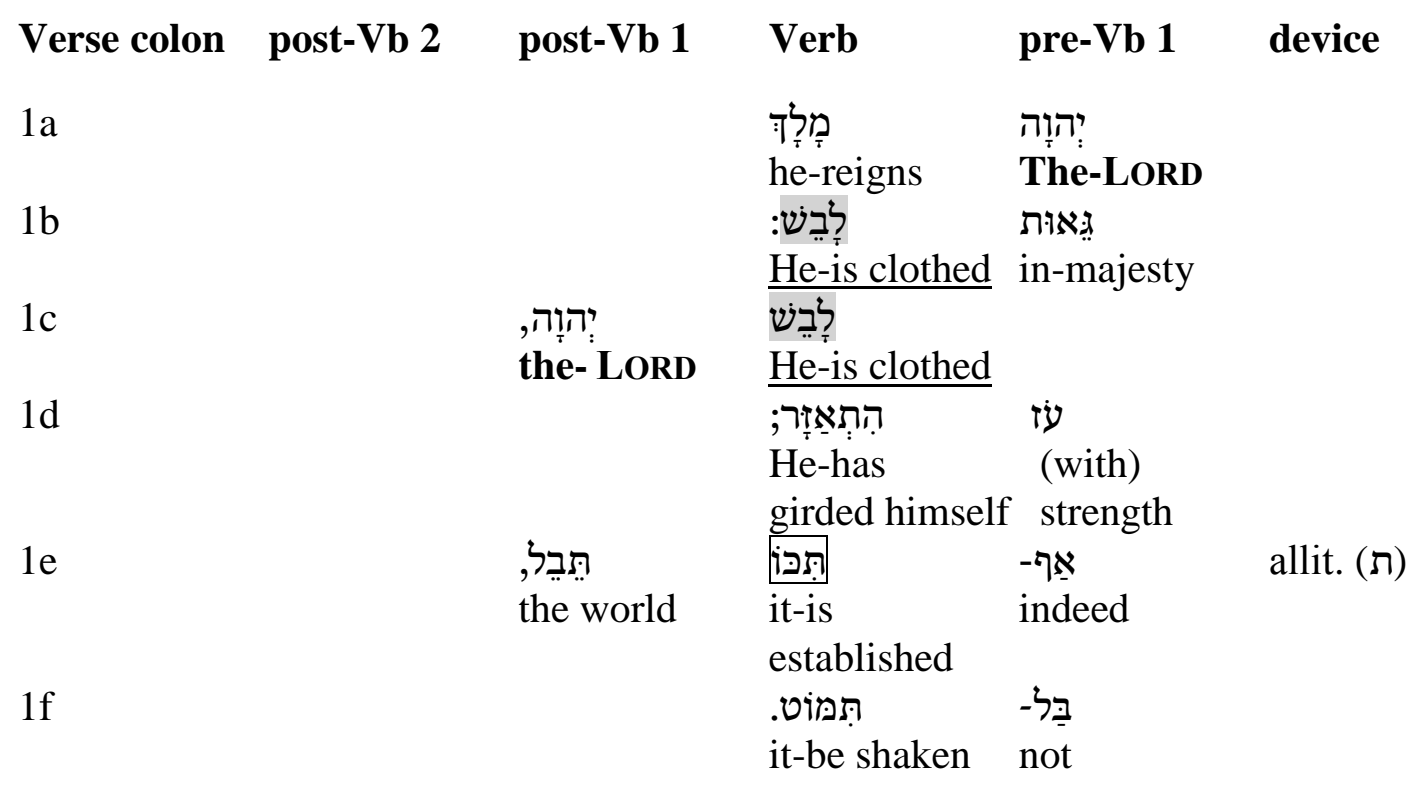

27 Hans-Joachim Krauss, Psalms 60-150 (Minneapolis: Augsburg, 1989).

28 Claus Westermann, The Living Psalms (Grand Rapids: Eerdmans, 1984), 124.

29 Howard, "Recent Trends," 8.

30 Bullock, Encountering, 190.

31 Erhard S. Gerstenberger, Psalms, Part 2 and Lamentations (Grand Rapids: Eerdmans, 2001), 175.

32 In the chart, repeated words/referents are marked in the same way (shading, underlining, bold). 
82 Dickie, "Literary-Rhetorical Analysis," OTE 30/1 (2017): 77-102

\begin{tabular}{|c|c|c|c|c|c|}
\hline post-Vb 3 & post-Vb 2 & post-Vb 1 & Verb & pre-Vb 1 & device \\
\hline $2 \mathrm{a}$ & $\begin{array}{l}\text { מָאזָ; } \\
\text { from-then } \\
\underline{y}\end{array}$ & $\begin{array}{l}\text { סֵאֶ: } \\
\text { Your- } \\
\text { throne }\end{array}$ & $\begin{array}{l}\text { נִּכוֹ } \\
\text { It is } \\
\text { established }\end{array}$ & & \\
\hline $2 b$ & $\begin{array}{l}\text { אָתָתה. } \\
\text { You } \\
\text { You }\end{array}$ & 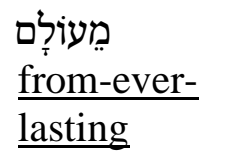 & & & \\
\hline $3 a$ & $\begin{array}{l}\text { ירוֹ: } \\
\text { LORD }\end{array}$ & $\begin{array}{l}\text { נִהָרוֹֹת } \\
\text { the floods }\end{array}$ & $\begin{array}{l}\text { נְשְׁאוֹ } \\
\text { they-have } \\
\text { lifted up }\end{array}$ & & alliteration (נ) \\
\hline $3 b$ & $\begin{array}{l}\text { קוֹלְׁם } \\
\text { their-voice }\end{array}$ & $\begin{array}{l}\text { נְהָרוֹת } \\
\text { the floods }\end{array}$ & $\begin{array}{l}\text { נָשְׁאו } \\
\text { they-have } \\
\text { lifted up }\end{array}$ & & $\begin{array}{l}\text { alliteration, } \\
\text { word-final } \\
\text { rhyme cf. 3c }\end{array}$ \\
\hline $3 c$ & $\begin{array}{l}\text { their-roaring } \\
\text { the }\end{array}$ & $\begin{array}{l}\text { נְהָרוֹת } \\
\text { the floods }\end{array}$ & $\begin{array}{l}\text { ישֶׁאו: } \\
\text { they-lift up }\end{array}$ & & \\
\hline $4 \mathrm{a}$ & & $\begin{array}{l}\text { מַיִם רַבִּים--- } \\
\text { many } \\
\text { waters }\end{array}$ & $\begin{array}{l}\text { מִקללוֹת, } \\
\text { Above-the } \\
\text { thundering }\end{array}$ & & $\begin{array}{l}\text { alliteration (מ̣) } \\
\text { clause-final rhyme } \\
\text { cf. 1st word in } 4 b\end{array}$ \\
\hline $4 b$ & 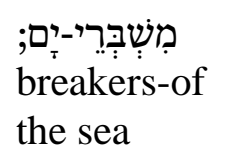 & $\begin{array}{l}\text { אַדִירִים } \\
\text { mighty }\end{array}$ & $\begin{array}{l}\text { (above-the } \\
\text { thundering) }\end{array}$ & & $\begin{array}{l}\text { alliteration (מ̣) } \\
\text { in } 4 b, 4 c, 5 a\end{array}$ \\
\hline 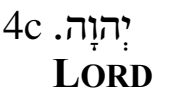 & $\begin{array}{l}\text { ד דבּפְּרָרוֹם } \\
\text { on-high }\end{array}$ & $\begin{array}{l}\text { mighty } \\
\text { mighe }\end{array}$ & (is) & & \\
\hline $5 \mathrm{a}$ & & $\begin{array}{l}\text { exceedingly } \\
\text { exced }\end{array}$ & $\begin{array}{l}\text { נֶאֶמנוּ reliable } \\
\text { are rele }\end{array}$ & $\begin{array}{l}\text { עֵדתֵתיף, } \\
\text { your-decre }\end{array}$ & \\
\hline 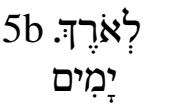 & 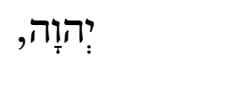 & קדָדש: & 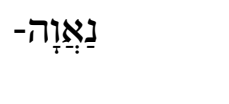 & לְביתתֶף & rhyme (final syllable) \\
\hline $\begin{array}{l}\text { for- } \\
\text { length } \\
\text { of-days }\end{array}$ & LORD & holiness & befitting & $\begin{array}{l}\text { to-your- } \\
\text { house }\end{array}$ & \\
\hline
\end{tabular}

Verse 1 opens with the proclamation יהוֹה מָלָּד "YHWH reigns." This is generally regarded as a formula (as it also opens Pss 97 and 99, and occurs in Ps 96:10). ${ }^{33}$ The second colon repeats the notion of the LORD as king with the word ("in] majesty”).

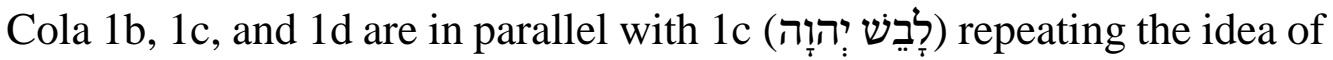
the LORD being "robed" and 1d (עז התתאזָזר) adding the concept of being "girded" (possibly referring to the belt to hold the robe in position). Thus anthropomorphic ideas are attributed to $\mathrm{YHWH}$, and the triple repetition emphasises that he is clothed as the divine warrior, ready to fight against chaos. ${ }^{34}$

33 Hossfeld and Zenger, Psalms 2, 448.

34 Hossfeld and Zenger, Psalms 2, 448. 
In vv. 1-2 and 5, there are also repeated notions of stability, seen in the

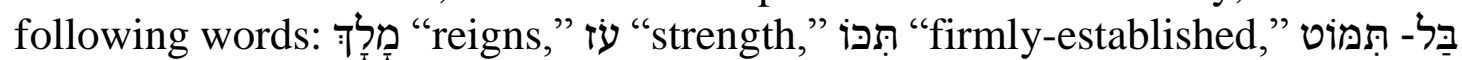

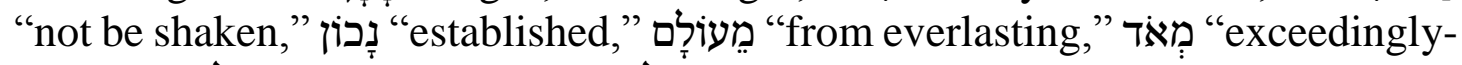

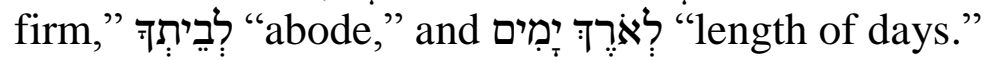

Jerse 3 shows threefold additive parallelism with the repetition of

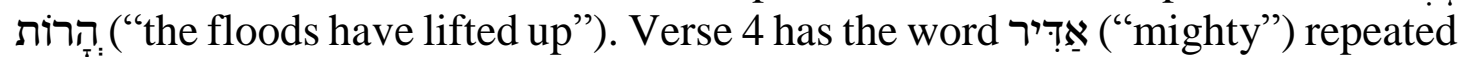
twice, but the phrase has the same notion in the description "above the thundering") which could be thought of as "more mighty than." The word ("LORD") is repeated 5 times, appearing in every verse except v. 2 (but twice in v. 1). It appears twice as a vocative (in vv. 3 and 5).

\section{$6 \quad$ Note Disjunction}

Verses 2, 3, and 5 are addressed directly to the LORD, whereas vv. 1 and 4 are in the 3rd person. There is thus a shifting pattern (indirect, direct, direct, indirect, and direct), indicating two voices (the psalmist and the narrator), which suggests antiphonal singing.

The rhythm changes significantly after v. 2, indicating a point of disjunction before v. 3 . The $2+2 / / 2+2$ metrical structure of the introductory cola contrasts noticeably with the $3+3+3$ pattern in vv. $3-5$. $^{35}$

Verses 3 and 4 are held together by their poetic pattern (threefold "additive parallelism") as well as thematically, and vv. 1 and 2 are also thematically united. The strong repetition of נָכוֹן ("it is established") in cola 1e and 2a, as well as מִעוֹלָם ("from everlasting / old") in colon 2b heightens the sense of the essential stability of the LORD, before the notion of chaos is introduced in v. 3. Thus the major disjunction is between vv. 2 and 3. Gerstenberger ${ }^{36}$ suggests that vv. 3 and 4 may have been an old poem remodelled by YHWH theologians. The content and rhythm suggest it is a unit apart, inserted into the frame of the psalm.

There is another point of disjunction after v. 4 , with v. 5 serving as the lower frame of the inclusio. However, there is a thematic link from v. 4 to v. 5: colon 5a gives the result of YHWH being victorious over the sea (in v. 4), namely the consolidation of his royal power resulting in the building of a temple, as in v. 5 b. ${ }^{37}$

35 Dahood, Psalms II, 340.

36 Gerstenberger, Psalms 2, 176.

37 Dahood, Psalms II, 343. 


\section{$7 \quad$ Note the Areas of Stylistic Concentration}

All five verses show an intensity of poetic language. The repetition in vv. 1-2 and 5 has been mentioned, as has the "growing waves" of chaos (v. 3) and of the power of the LORD (v. 4), produced through repetition of an additive nature.

In v. 1, the position of יהוָה (YHWH) before the verb gives focus to the truth that YHWH (and no other deity) exercises kingship. Also in v. 1e, the use of - אֵ emphasises the statement being made, as evidenced by the Ugaritic equivalent being an emphatic conjunction. ${ }^{38}$

Verses 3 and 4 both show 3-fold repetition which Willis ${ }^{39}$ refers to as tricola. He claims that "Tricola gave the psalmist an opportunity to build a thought or an emotion to a climax." Gerstenberger ${ }^{40}$ agrees that "The nucleus of the hymn is verses 3 and 4," and observes that the language is redundant and very rhythmic. He notes that each colon in v. 3 has two "stock words," namely (ְשְשָאוּ ("they have lifted up") and ("floods"), but also an alternate word: first קוֹלְם , יְרוֹ ("YHWH") in place of a grammatical object, and then suffixed nouns

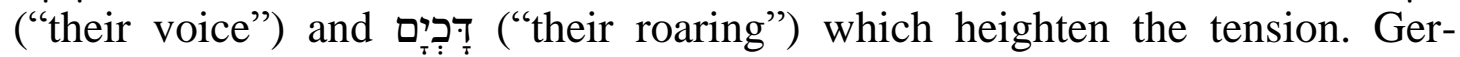
stenberger asserts, too, that v. 4 shows three tightly-knit cola, ascending to the final word, יהוֶ: (YHWH). The build-up through vv. 3 and 4 to this final victorious ring emphasises his ascendancy.

\section{Identify the Structure of the Text}

The psalm consists of three poetic strophes: vv. 1-2, vv. 3-4, and v. 5. ${ }^{41}$ The first two verses include threefold parallelism which builds a "foursquare solidity" with God's sovereignty as "a structural fort." 42 There are two alternating voices: a leader expressing truths about YHWH $(\mathrm{vv} .1,4)$ and the choir addressing YHWH directly (vv. 2, 3, 5).

The psalm shows a careful poetic structure with vv. 1-2 and 5 forming an inclusio, with notions of stability and enduring ("from everlasting" and "for length of days"). ${ }^{43}$ Gerstenberger ${ }^{44}$ supports this idea, maintaining that verses 3

\footnotetext{
38 See Dahood, Psalms II, 340.

39 John T. Willis, "The Juxtaposition of Synonymous and Chiastic Parallelism in Tricola in Old Testament Hebrew Psalm Poetry," VT 29 (1979): 465-480.

40 Gerstenberger, Psalms 2, 174-175.

41 Nancy deClaisse-Walford, Rolf A. Jacobson, and B. LaNeel Tanner, Overview of the Shape and Shaping of the Book of Psalms: The Current State of Scholarship (Atlanta: SBL Press, 2014), 706.

42 Eugene H. Peterson, Where your Treasure Is (Grand Rapids: Eerdmans, 1985), 54.

43 Dahood, Psalms II, 340, from his reading of "enthronement" in v. 5 instead of "decrees," sees the inclusio framed by "your throne ... of old" (v. 2) and "your enthronement was confirmed of old" (v. 5).

44 Gerstenberger, Psalms 2, 174.
} 
and 4 "are framed by direct adoration of YHWH by the congregation." DeClaisseWalford et al. ${ }^{45}$ also assert that "verse 5 serves as a thematic inclusio for the psalm."

Contra this notion, Hossfeld and Zenger ${ }^{46}$ believe that literary and redaction criticism suggest that v. 5 was a later addition. They consider the opening formula in colon 1a as a thematic statement, and set it apart. The remaining clauses (excepting v. 5) then form a tricola structure with asymmetric parallelism, a characteristic of Ugaritic poetry, and in the Psalter a sign of antiquity. However this then disturbs the chiastic patterns seen in v. 1 ("LORD"/“clothed"//“"clothed"/“LORD") and v. 2 ("your throne"/“from old"//"from everlasting"/"you"). Moreover, v. 5 shows unity in rhythm with vv. 3 and 4 , each having 3 poetic lines, and thus the inclusio notion (formed by vv. 1-2 and v. 5) is preferred.

Within the inclusio are two key ideas: first, the matter of growing chaos (in v. 3) countered in v. 4 by the increasing notion of the might of the LORD. Both vv. 3 and 4 show threefold additive parallelism. ${ }^{47}$ The rhetorical power of the triplet in Ps 93 becomes more evident when contrasted with similar imagery in Ps 46:2-3 (double parallelism) and Ps 124:3-5 (triple image, but without ascending strength).

\section{Do a Semantic Study}

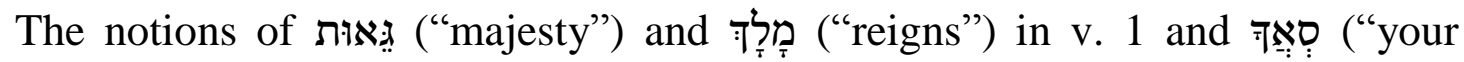
throne") in v. 2 are all linked with the concept of YHWH as the king. In colon 2b, parallelism suggests that אָָ should be interpreted as "your throne / royal position" rather than "you" referring to the LORD's existence. The NET Bible argues: "As the context suggests, this refers specifically to God's royal position, not his personal existence." However, Hossfeld and Zenger ${ }^{48}$ assert that as "throne" and the existence of God are in parallel, the implication is that "the world shares in the stability and the endurance of God's existence and rule." Thereby they equate the two senses of "existence" and "rule." All of the translations consulted express the colon with the sense "you are eternal." Nevertheless, the Translator's Handbook ${ }^{49}$ suggests that "... since then you have been king" is acceptable, indicating that the topic is "kingship" rather than "you."

45 DeClaisse-Walford, Jacobson, and Tanner, Shape and Shaping, 708.

46 Hossfeld and Zenger, Psalms 2, 447-8.

47 Westermann, Living Psalms, 230 and 17 calls this "climbing or step parallelism" and notes that it occurs only here and in Ps 29 . He observes that "this particularly artistic form" is also seen in Ugaritic texts.

48 Hossfeld and Zenger, Psalms 2, 448.

${ }^{49}$ Robert G. Bratcher and William D. Reyburn, A Translator's Handbook on The Book of Psalms (New York: United Bible Societies, 1991). 
Verses 3 and 4 have Ugaritic and Canaanite mythology as their background: Baal fights and defeats the chaos-enemy, Sea. ${ }^{50}$ For ancient Israel, the sea symbolised the feared unknown. By metonymy, it may also refer to the hostile nations who opposed Israel and thus YHWH. ${ }^{51}$ It links back also to the threatening waters before order was first instituted in the Creation, with the separating of the land from the sea (Gen 1:6). The turbulent waves growing in crescendo is a vivid picture of increasing chaos (yet under YHWH's control, as indicated in v. 4). Also, the vocative in colon $3 \mathrm{a}$ indicates the threat (from a human perspective) of the waters (נהרוֹת). There are two interpretations as to what the "waves" are doing: praising YHWH or threatening him. ${ }^{52}$ DeClaisseWalford et al. ${ }^{53}$ believe that "the waters rise not to destroy but to praise their Creator." They suggest "waters" echoes Exod 14 where God, in his supremacy, used the rising waters to destroy the enemy. In either case, the truth expressed is that YHWH is greater than the waves.

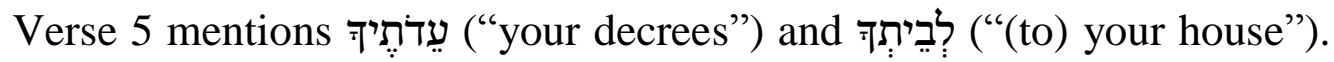
These refer to what the LORD has said and who he is (his presence among his people). Both are sure and to be trusted forever. Not only did the LORD establish the world (v. 1), and his reign in the world (v. 2), he also established his firm decrees to govern it (v. 5).

The meaning of קדָש ("holiness") is often "altogether other" (characteristic of God alone) and that could be the sense here, in parallel with v. 5a נֶֶֶמנוּ "firm." This attribute is in contrast with the changing nature of the world: he is always the same, and to be trusted for his stability.

The Hebrew verb נַאָוזה ("becometh/be beautiful") used in v. 5 with "holiness" emphasises his "altogether otherness" gives beauty to the place where he is present. Some translations (e.g. NEB, TOB, and NJB) interpret the Hebrew verb נְַּוָה ("befits") as a noun, namely "holiness is the beauty of your house."

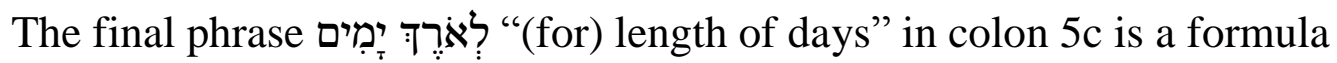
throughout the Psalter. ${ }^{54}$

50 Hossfeld and Zenger, Psalms 2, 449.

51 Cf. Isa 57:20; Jer 49:23.

52 Brueggemann and Bellinger, Psalms, 403.

53 DeClaisse-Walford, Jacobson, and Tanner, Shape and Shaping, 707.

54 Hossfeld and Zenger, Psalms 2, 449. 


\section{Study the Phonic System and Other Poetic Features}

The word-repetition is highlighted in the annotated text. Apart from that, there is some alliteration of $\Omega$ in cola 1e and 1f, $מ$ in $2 a$ and $2 b, D$ in $4 a, 4 b$, and $4 c, J$ in $5 \mathrm{a}$ and $5 \mathrm{~b}$, and assonance of the word-final 7 in $5 \mathrm{a}$ and $5 \mathrm{~b}$. The alliteration in vv. 3-4 adds emotive impact to the growing chaos and the increasing victory of the LORD, and serves a mnemonic function. The structural poetic features of chiasm and inclusio (already mentioned) add to the rhythm and memorability of the text.

The two central verses ( 3 and 4) show a carefully-constructed, regular rhythm: each of the cola in v. 3 has 8 syllables, and in v. 4 each colon has 7 syllables. ${ }^{55}$ This makes them easily singable, and supports the notion that they were originally a chorus that was borrowed and inserted into the psalm.

\section{Note the Speech Functions ${ }^{56}$}

By using highly evocative language in vv. 3 and 4 , the psalmist wishes to encourage the audience of the victory of the king regardless of growing chaos, because of his essential stability and kingship-attributes (emphasised in the inclusio).

The enelage ${ }^{57}$ in v. 2 , when the LORD is addressed directly, emphasises that the psalmist is in the presence of the LORD, in the "holy place" (v. 5), even as he declares his praise. This links with the cultic function of the psalms, to bring the worshipper into the presence of the Almighty.

The rhetorical devices in Ps 93 serve the following functions:

- The heightened poetical language in vv. 3 and 4 (with the threefold repetition of the topic and verb, and the additive parallelism) highlight these two verses as the main message of the psalm.

- The repetition of verbs in vv. 1-2 ("robed" twice in v. 1, and "established" in v. 1c and v. 2a) facilitate memorisation, and emphasise the message being conveyed, namely the majesty of the LORD, and the settled-ness of his creation, his throne, and his person (indicated by "established" and "from of old / everlasting").

- the picture of stability and trustworthiness painted in vv. 1-2 through the use of נָכוֹ ("established"), מָאזז ("from of

\footnotetext{
55 Dahood, Psalms II, 341. Cola 4a and 4b have plural adjectives referring to God (אַדַירִים and), the plurals probably chosen for metrical considerations. In colon 4c, the adjective אַּ is singular to keep the syllable count to 7 (as in cola $4 a$ and $4 b$ ).

56 The speech functions support the rhetorical function of the text.

57 An enelage is a typical feature of Hebrew poetry where the pronominal references suddenly shift within the same poetic unit/strophe (here vv. 1-2).
} 
old") and ("מעוֹלָם ("from everlasting") is indicated again in v. 5 with the

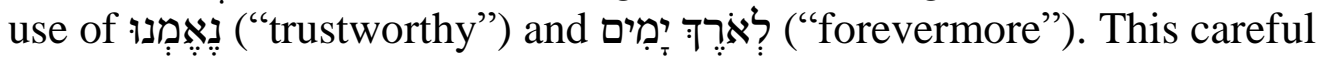
use of related semantic content at the boundaries of the psalm gives unity to the psalm, and frames the main point (in vv. 3-4) with the reasons for this truth.

- The repetition of ("he is clothed") at the end of v. 1b and the beginning of v. 1c moves the text forward.

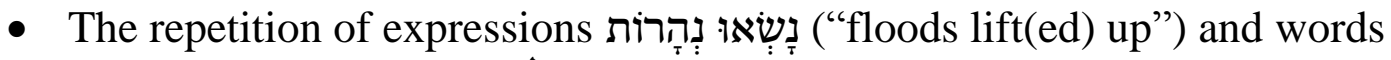

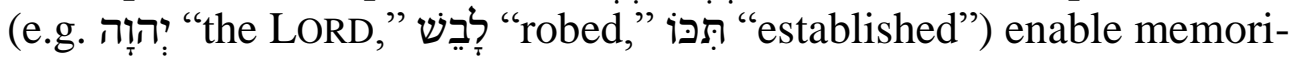
sation of the text and provide aesthetic appeal.

- The use of ("indeed") in v. 1e, and the repetition of נָכֹ ("it is

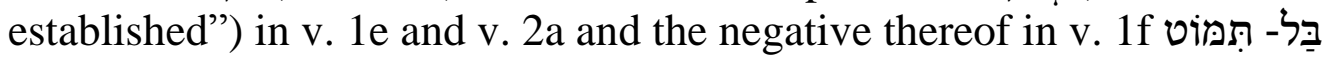
("not be shaken") emphasise the sense of settled strength pertaining to the LORD, before the introduction of contrary forces in v. 3.

- The 3-fold repetition of the first two words in the cola of v. 3 has great rhetorical effect, symbolising growing chaos or opposition. The variation in the last word of each colon sustains interest.

- The initial consonant is repeated five times in cola 4a, 4b, 4c, and 5a. This alliteration serves an aesthetic function and assists with memorising. Similarly assonance in the first two words of v. $5 \mathrm{~b}$ has a mnemonic and aesthetic function.

- In v. 4 the second two cola (v. $4 \mathrm{~b}$ and v. 4c) have an inferred verb (from v. 4a); this deletion of the verb (ellipsis) in the latter two cola moves the text forward quickly, to the ultimate word of triumph in v. 4c.

- ירוזה ("LORD”) at the end of v. 4c is not the normal position for the subject, and highlights the truth: the one who is mightier than all else is ... YHWH!

- The interjection of the vocative יהוּ: ("LORD”) in v. 5b puts the final

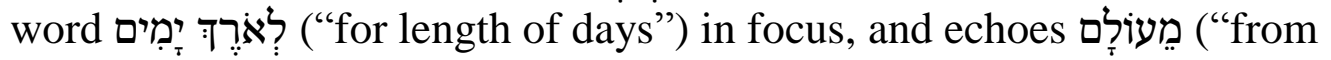
everlasting") in v. 2b. Just as he is forever, and his holiness is forever, his victorious power over all foes (v. 4) is true for all time.

\section{Find Form-Functional Matches in the Receptor Language}

Parallelism is common in Zulu poetry, and thus can be freely used (as in the Hebrew of vv. 3, 4, and 5). Also, the 4-line pattern of parallelism is common (e.g. in the Shakan izibongo ${ }^{58}$ ), with a statement, extension, development, and

58 See Duncan Brown, Voicing the Text: South African Oral Poetry and Performance (Cape Town: Oxford University Press, 1998), 94. 
conclusion. If vv. 1 and 2 of Ps 93 are slightly adjusted, this 4-line pattern emerges:

1a The LORD is king! He is robed in majesty.

1b Indeed, the LORD is robed in majesty and armed with strength. Stant

2 Your throne, O LORD, has been established from time immemorial. Development You yourself are from the everlasting past.

1c The world is firmly established; it cannot be shaken. Conclusion

With respect to vv. 3 and 4 of Ps 93, some izibongo show the same 3-fold additive repetition, for example Izibongo of Senzangakhona:

UMlunguzi wezingoje, "Peerer over precipices

Owalunguz' ingoje yomfowabo, Who peered over the precipice of his brother

Owalunguz' ingoje kaZivalele. Who peered over the precipice of Zivalele."

Thus the tricola pattern seen in the Hebrew of the psalm can be followed in isiZulu, being a natural form of Zulu poetics. Also, Zulu praise-poems sometimes show the structural form of chiasm $^{59}$ (with the same mnemonic function), and thus the chiastic structures seen in the Hebrew text (e.g. vv. 1a-b and 1c, or $2 \mathrm{a}$ and $2 \mathrm{~b}$ ) can be replicated. One further notion common to both Hebrew and isiZulu is apparent in v. 5, namely that of poetic rhythm. The first four verses refer to the unchanging nature of YHWH, regardless of challenges that rise against him or his people. Verse 5 shows a variation to this pattern, with a switch to his Word and his house (rather than his person). This draws attention to the verse, which declares a key truth: YHWH is king forever, like no other.

Once the Hebrew analysis is complete (as above), the second phase of the methodology is implemented. An empirical study was conducted in which isiZulu-speakers participated in workshops where they translated and performed selected psalms (including Ps 93). This is discussed in the next section, after which the final stage of the methodology is presented, namely the evaluation of the workshop translations.

\section{MAKE A PROVISIONAL TRANSLATION}

Poets ${ }^{60}$ or musicians in the community were invited to a series of three one-day workshops at which they were exposed to the basics of translation principles and poetic/oral devices. Four workshops were held in all: with a church youth-group in AmaOti (Durban), members of various Anglican churches in Pietermaritzburg, some students at the Lutheran Theological Institute

59 For example: "Chopper down of the big tree; the little one falls on its own." See Elizabeth Gunner, "Wand or Walking Stick? The Formula and its Use in Zulu Praise Poems," in The Oral Performance in Africa, ed. Isidore Okpewho (Nigeria: Spectrum Books, 1990), 195.

60 Most of the participants in this empirical study would not call themselves "poets" but "poetry fans." 
(Pietermaritzburg) and some members of the Tree of Life poetry group in Pietermaritzburg. At each workshop, the poetic devices apparent in the Hebrew text were discussed, as well as typical poetic devices used in Zulu poetry. Each day one psalm was in focus, and after discussing the exegetical and poetic issues, the participants used their own innate skills to make a translation in line with the forms of Zulu poetry and music. Once the translations were considered sufficiently accurate (with exegetical assistance, if needed, from the researcher), ${ }^{61}$ poets proceeded to convert their poems into performance-items, either spoken or sung. Each day they performed their items before their peers, and at the end of the workshop, a selection of items were performed before a public audience. Most of the performances were recorded, both audio and video. The participants showed great interest and pleasure in engaging with the biblical text, making their own translations (thereby "getting inside the black box" of Bible-translation), and using their creativity in performance to present a dynamic message.

\section{ASSESS THE SUCCESS OF THE WORK}

In order to assess the quality of the empirical translations, the third step of the methodology was incorporated, namely the application of six "evaluation criteria." Three of the criteria are those traditionally used in evaluating Bible translations. $^{62}$ These are accuracy (to the original text), naturalness of language, and clarity of understanding. In this study, accuracy (or faithfulness to the source text) was assessed by the researcher, and naturalness and clarity were evaluated by the audience and reported through interviews. This latter data was gathered after the performances of the translations when interviews were conducted with a sample of audience members and participants. ${ }^{63}$

The additional three criteria used in this study are those necessary to evaluate performance-based, literary-rhetorical translations. ${ }^{64}$ These are (literary) artistry, aurality, and acceptability. Literary artistry and aurality were assessed by the researcher, and acceptability (of the item's "biblical authenticity") was evaluated by the audience. The six criteria are next considered with some isiZulu examples.

61 Two mother-tongue speakers, Tankiso Mokoena and S'fiso Hlongwa, served as research-assistants, and made a valuable contribution.

62 Eugene A. Nida, Towards a Science of Translating: With Special Reference to Principles and Procedures Involved in Bible Translating (Leiden: Brill, 1964).

63 The interviews with participants had a different goal than those with audience members. The former sought to assess the value the participants gained through the workshop process, whereas the latter focused on the products of the workshops, viz. the performed translations.

64 Ernst R. Wendland, Translating the Literature of Scripture (Dallas: SIL, 2004), ch. 10 . 


\section{Criterion of Accuracy}

Most of the poets succeeded in conveying the main notions of the LORD described in v. 1 of this psalm (viz. he is king, and has "majesty" and "strength") as well as the truth that the world is "established." Consideration will now be given to the individual Hebrew words ${ }^{65}$ in each verse, with a view to their translation into isiZulu.

\section{1a Verses 1-2}

יהוֹה The divine name was variously translated. Some used the borrowed word UJehova, others chose to use Somandla (Powerful One), which reflected the theme of power (amandla) in v. 4. A popular option was Simakade (eternal one), connected to the word phakade meaning "forever."

מָלדָ ("reigns") was translated mostly as uyinkosi (related to nkosi = "king"), but an alternative was uyabusa ("govern").

לבֵבש is defined as "to be clothed," and was translated by wembeth ("clothed") in most translations. Alternatives were vunula ("robed"), -bhinca ("put on") or -ugqoke / -ufaka ("wearing").

ๆ ("Indeed”) was translated literally by some poets (Impela) but others showed the emphasis through repetition, as in the example below:

1e Uqinile ungeguqulwe yilutho
Firm, can shake it nothing
1f. Ungeguluqulwe yilutho.
Can shake it nothing

The following translation showed the emphasis by having two statements in parallel, one positive and one negative:

$\begin{array}{rll}\text { 1d Umhlaba } & \text { umile ugxilile } \\ & \text { The earth } & \text { stands firm } \\ \text { 1e Umhlaba } & \text { awnnakuthikaziswa } \\ \text { The earth } & \text { is undisturbed }\end{array}$

תֵּ is defined as "to be established," and appears in the Hebrew text in both v. 1 and v. 2. The isiZulu translations used various words: -ugxilile ("firm"), -imiswe/-imile ("stands"), -julile ("deep"), -qinile ("firm"), or sabekwa ("put there"). One poet emphasised the characteristic "established" by using a tail-head

65 Definitions of Hebrew words come from Francis Brown, S. R. Driver, and Charles A. Briggs, Hebrew-English Lexicon (incorporated in Translators Workplace, SIL and UBS, 2008) and R. Laird Harris, Gleason L. Archer Jr, and Bruce K. Waltke, eds., Theological Wordbook of the Old Testament (NavPress Software, incorporated in Translators Workplace, SIL and UBS, 2008). 
linkage in $1 \mathrm{~d}$ and $1 \mathrm{e}$, and a chiasm (repeating the key attribute) in $2 \mathrm{a}$ and $2 \mathrm{~b}$. This is shown below:

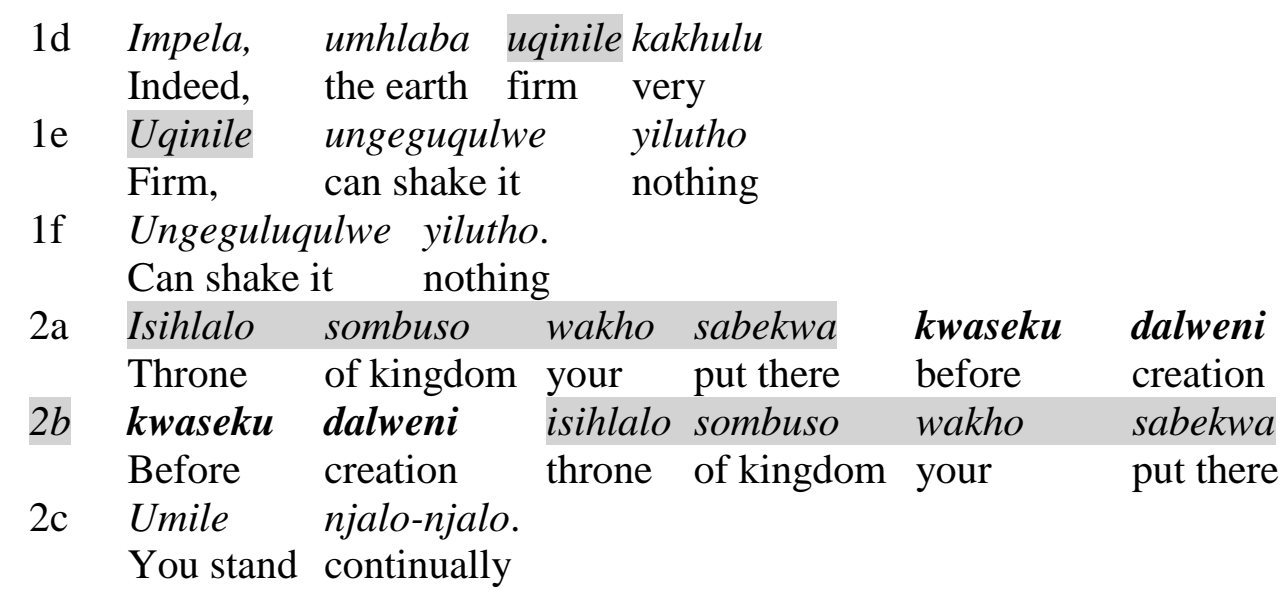

Another poet omitted the notion of the world being established, but used parallelism to emphasise that the LORD's throne / kingdom is "established":
1b umbuso wakhe unyehlulwa.
Kingdom his has never been defeated.
2a Umbuso wakho, indalo yakho imile kusukela ekudalweni.
Kingdom your creation your stands originating from

creation.

In v. 2, most translations indicated that it was "your kingdom/throne" which is "everlasting," which is in the Hebrew text, but so too is the notion that "You (i.e. the LORD himself) are from everlasting." This was captured in some translations, for example:

$\begin{array}{llll}\text { 2a } & \text { Isihlalo } & \text { wakho, } & \text { Jehova, sijulile kwaseku qaleni, } \\ & \text { Throne } & \text { your } & \text { LORD firm from the beginning } \\ \text { 2b futhi } & \text { wena } & \text { khona ekuqaleni. } \\ \text { And } & \text { you } & \text { there from the beginning. }\end{array}$

The notion of "you are from everlasting" was missing in most translations, but (as discussed earlier), if the idea of his kingship being eternal is included, it would seem to be acceptable. For example:

$\begin{array}{lllll}\text { 2a } & \text { Isihlalo } & \text { sakho } & \text { sobukhosi simiswe ekugaleni } \\ & \text { Throne } & \text { your } & \text { of kingdom stands from beginning } \\ \text { 2b } & \text { Isihlalo } & \text { sakho } & \text { simile kuze kube phakade } \\ & \text { Throne } & \text { your stands forever }\end{array}$

\section{1b Verse 3}

The imagery of (ְָהרוֹת ("floods") in v. 3 was maintained in some poems, as well

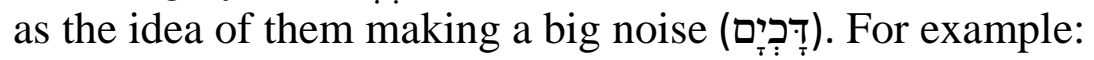




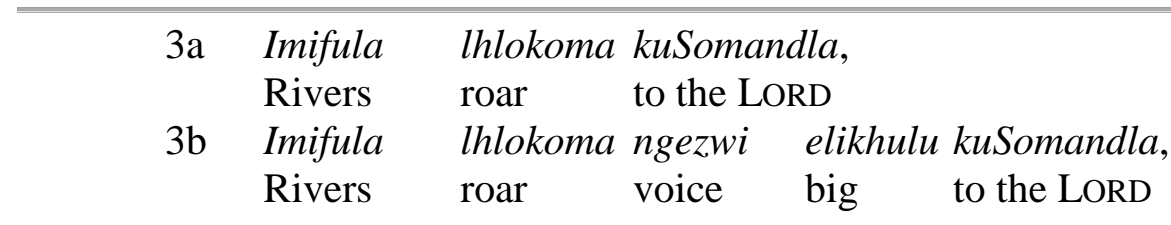

In discussing the text, it was noted that one could maintain the metaphor, adapt it to another (if the Hebrew metaphor was not particularly meaningful), or apply it. Among different metaphors used, the most popular was that of "strong wind." Perhaps this was an attempt to maintain an image from nature that was part of the poets' common experience. An example using this imagery follows:

$\begin{array}{lll}\text { 3b Izivungu-vungu } & \text { ziyavunguza, } & \text { Mdali } \\ \text { Gales } & \text { blowing } & \text { Creator }\end{array}$

Others combined several metaphors in the same item. A metaphor that appeared several times was that of "fire," as in the example below (which also uses two ideophones ${ }^{66}$ ):

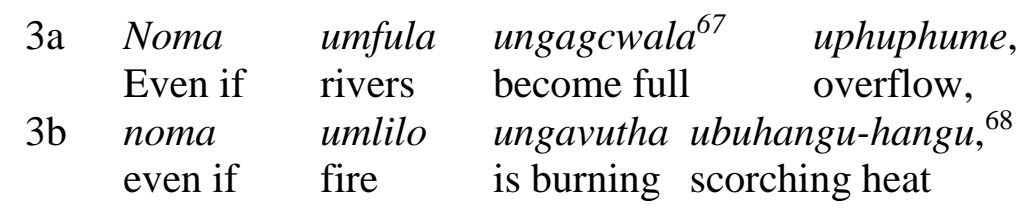

Other poets interpreted the "floods" as enemy attacks. For example:

$\begin{array}{llll}\text { 3a Noma } & \text { isitha } & \text { singahlasela, } & \text { Jehova } \\ \text { Even if } & \text { the enemy attacks, } & \text { LORD }\end{array}$

Or the "floods" were interpreted as temptations, as in the example below:

$\begin{array}{llll}\text { 3a } \begin{array}{lll}\text { Izilingo } \\ \text { Temptation }\end{array} & \text { noma } & \text { ziyanda, } & \text { Simakade, } \\ \text { if it increases, } & \text { LORD, }\end{array}$

Some combined images in various ways; the poem below uses a metaphor (wind), a simile (like a lion), and an application of the original metaphor (an enemy) within the same poem.

$\begin{array}{lllll}\text { 3a } & \text { Nakuba isitha sibhodla okwebhubesi, } & \\ & \text { Even tho' enemy roaring like a lion, } & \\ \text { 3b } & \text { Nakuba izivunga-vunga zisihlasela } & \text { ngamandla, } \\ & \text { Even tho' strong winds attacking } & \text { with strength, } \\ \text { 3c } & \text { Nakuba, umoya uvunguza } & \text { ngamandla, } \\ & \text { Even tho' wind } & \text { (is) blowing strongly } & \text { with power, }\end{array}$

66 The use of ideophones adds enormously to the audience's pleasure and sense of the text being "our language."

67 Gcwala is an ideophone indicating to be full to capacity.

68 Hangu is an ideophone connected with scorching heat. 


\section{1c Verse 4}

The metaphor in the Hebrew of v. 4 relates to that in v. 3, and most poets did so in their translations. When there were two different metaphors in v. 3, the poet generally referred to both in v. 4 , as in the example below:

3a Nakuba isitha sibhodla okwebhubesi,
Even tho' enemy roaring like a lion,
3b Nakuba, izivunga-vunga zisihlasela ngamandla,
Even tho' strong winds attacking with strength,
4a inamandla Nkosi ngaphezu kwebhubesi
Powerful LORD greater than the lion
4c inamandla Nkosi ngaphezu kwezivungu-vungu ezivunguza ngamandla
Powerful LORD above that storm that is blowing with power

However, one poet added a new metaphor in v. 4 (that of "a mountain," considered to be "the highest") to emphasise that the LORD is higher than the highest thing known to man. Another translation introduced completely new metaphors in v. 4 (relative to v. 3). This probably diminished the force and cohesiveness of the argument in the original.

In terms of expressing the power of the LORD in v. 4, the word-amandla ("power") was repeatedly used. Some poets added other notions, which can be implied from the Hebrew text, for example -ngeyakufaniswa ("incomparable"); ziyakulalela ("they listen to you").

\section{$1 d \quad$ Verse 5}

עַדֶתיף, the first word in v. 5, is defined as "laws," and was translated by imithetho ("rules"), imiyalo ("instructions") or izimiso ("statutes"). The verb in 5a נֶמֵמנוּ means "established," and was rendered by ithembekile ("faithfulness"), ayijiki ("not changing"), kayigudluki ("immovable"), imile ingunaphakade ("standing forever"), azinalaguquka ("cannot be changed") or ayiqiniso impela ("true indeed").

With regard to נַאַוָה ("seemly, beautiful") in 5b, TWOT notes: "In Psalm נקאמננו: 93:5 it would seem better to translate 'befitting' since the parallel idea "faithful, steady." "69 Most translations included the notions of "holiness" being "beautiful" or "filling (the house)." However, in some examples, the Hebrew verb was not translated, but holiness was ascribed to the LORD's "house." "70 For example:

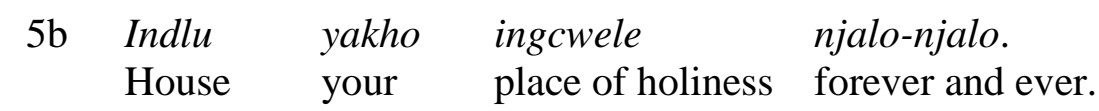

69 Harris, Archer and Waltke, Theological Wordbook of the Old Testament.

70 In Zulu thinking, "house" implies the dynasty or household of the king. 
Generally, the main information content of the original text was captured in the empirical translations. Some small exegetical errors are apparent, but for the most part, the translations were effective in communicating the eternal kingship of the LORD, including in creation. This was only the second exercise in translation the poets had ever done, and thus their efforts are commendable. Next the artistry and orality of the compositions was assessed.

\section{Criterion of Literary and Rhetorical Artistry}

In evaluating literary-rhetorical translations, it is important that the genre of the receptor translation be valid. Psalm 93 is a psalm of descriptive praise; besides lifting up the name of YHWH, it also gives reasons for the praise. It is a kingship psalm, and much of the vocabulary pertains to the character and function of a king. The isiZulu translations are also in the form of poems (or songs) of praise, following the style of izibongo, praise-poems describing the actions and character of a king. Thus this genre is appropriate for Ps 93.

The literary and rhetorical devices used in the Hebrew text have been studied and the functions achieved by these devices have been delineated. The isiZulu translations must achieve the same functions, using their own particular poetic devices natural to Zulu poetry. In summary the following functions must be achieved in the empirical translations:

(i) Unity of vv. 1-2 and 5 so that the unity in the original text is maintained

(ii) Unity of vv. 3-4 (the "chorus"), and strong rhetorical force in vv. 3-4

(iii) Mnemonic features

(iv) Aesthetic features

These functions are fulfilled in various ways in the isiZulu translations (in quantity and quality, although not in form). The poetic features utilised often serve more than one function simultaneously. For example, they may assist with memorisation and provide aesthetic pleasure, and the repetition of sounds and words (which unites different parts of the poem) also make the text more memorable and pleasing. Some examples of these poetic devices follow, revealing that the isiZulu compositions succeeded in satisfying functional equivalence through their use of Zulu poetic devices.

\section{2a Unity of Boundaries of Psalm}

In the Hebrew text, a thematic inclusio is apparent in vv. 1-2 and v. 5. These verses frame the peak content (in vv. 3-4). The isiZulu example below shows a similar unity of ideas in vv. 1-2 and v. 5 through the use of many repetitions: Jehova and -zwi (vv. 1-2, 5), -nkosi (vv. 1-2), bungobakho (vv. 1, 5) and kuze kube phakade (vv. 2, 5). 
96 Dickie, "Literary-Rhetorical Analysis," OTE 30/1 (2017): 77-102

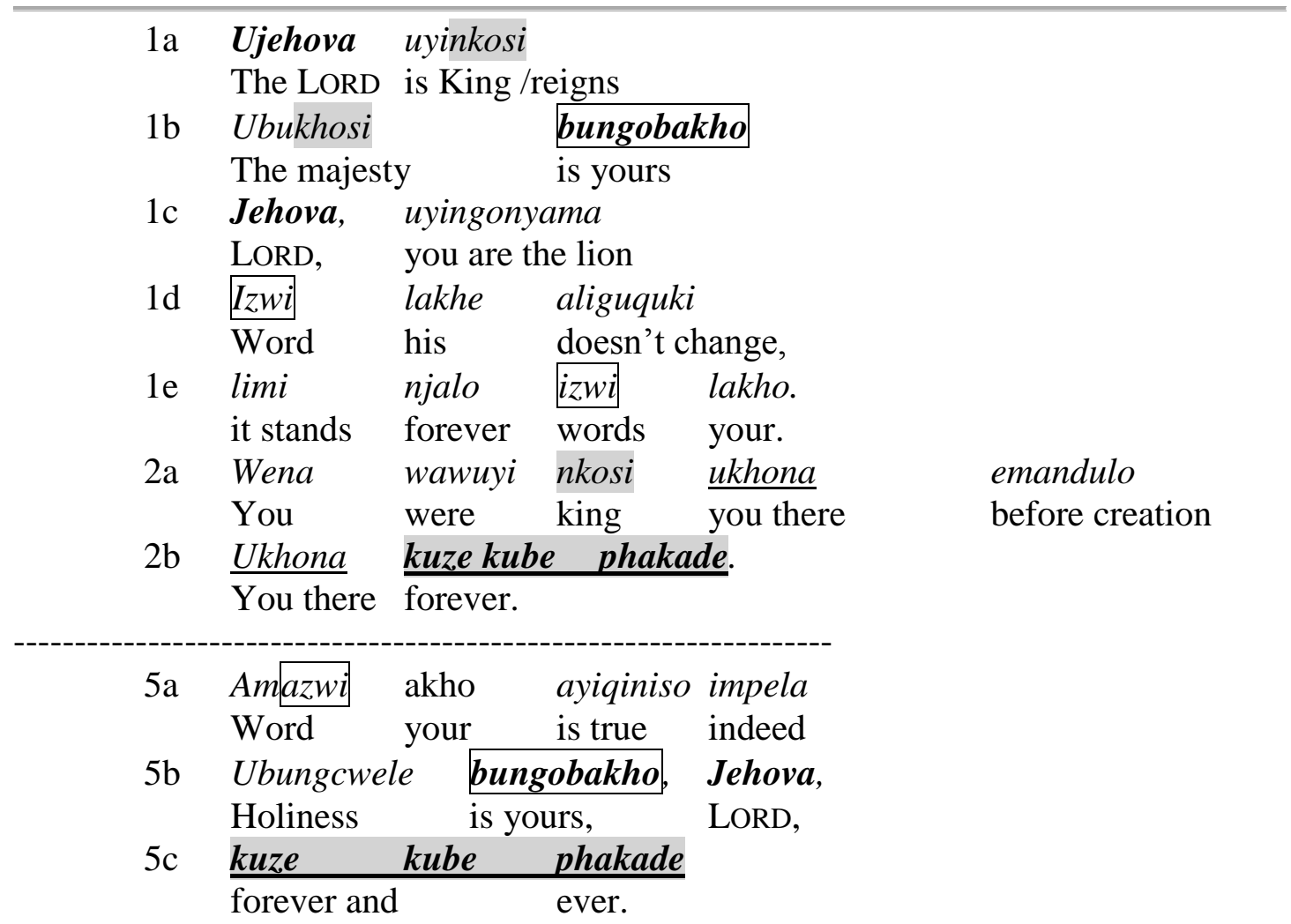

\section{2b Unity and Rhetorical Force (in vv. 3-4)}

The peak verses in the Hebrew psalm (vv. 3-4) show a unity of vocabulary and very strong emotive power (through the tricola structure). As indicated earlier, isiZulu praise-poems can show a tricola pattern, and the example below shows such 3-fold parallelism clearly in both v. 3 and v. 4 . The repetition of words and sounds (through assonance and alliteration) unites the two verses giving a stirring message. The imagery shows development from $3 \mathrm{a}$ to $3 \mathrm{c}$ (with increasing menace). Verse 4 also uses parallelism and repetition (-amandla and -ngaphezu) to give rhetorical force to the main message of the psalm (the LORD more powerful than all difficulties).

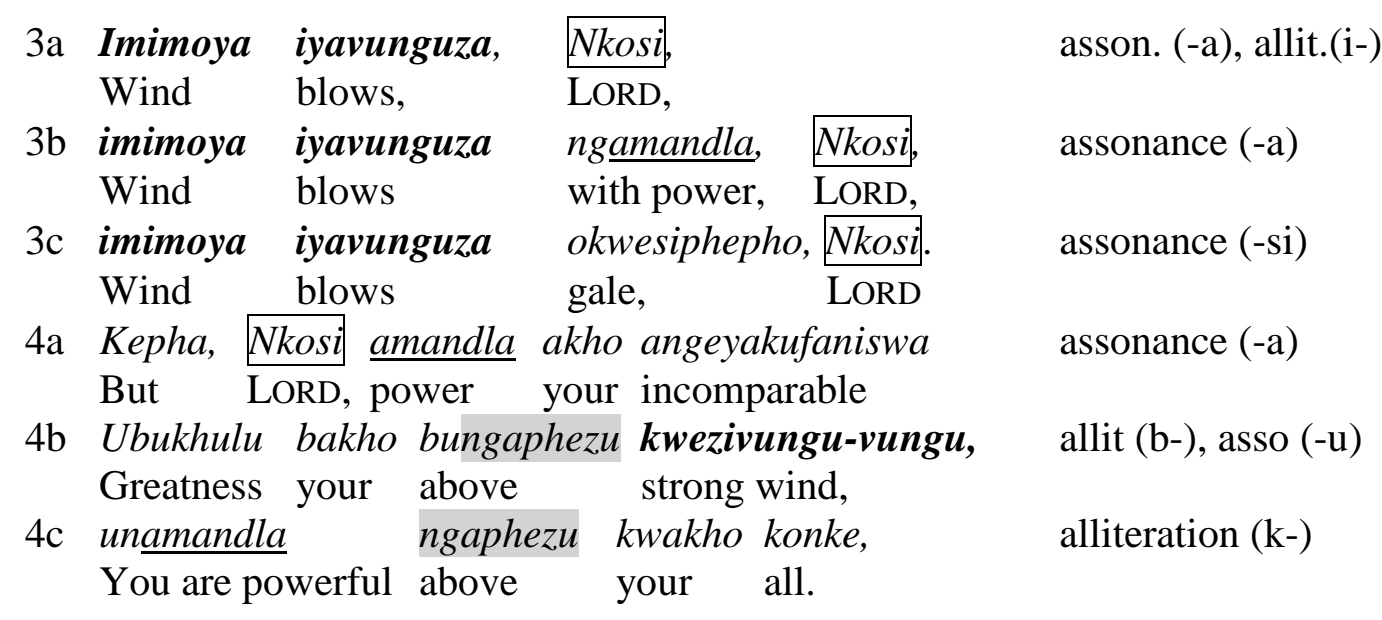


The next example uses several poetic devices to add rhetorical force to vv. 3-4: initial linkage repetition across all three cola, repetition in 4c, a short poetic line in $4 \mathrm{c}$, and the omission of the final vowel in the last two words in $4 \mathrm{c}$.

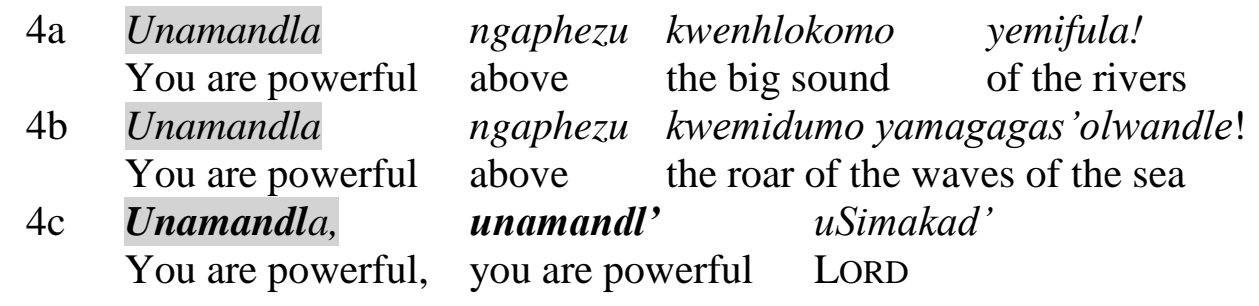

The following example shows repetition of the topic and verb (both $3 x$ ), as well as the repetition of olwandle and ngamandla in $3 \mathrm{~b}$ and $3 \mathrm{c}$. These repetitions give strong rhetorical force to this verse. The short poetic line in $3 \mathrm{~d}$, with no repetition, comes as a contrast and adds to the rhetorical power, drawing attention to the declaration made.

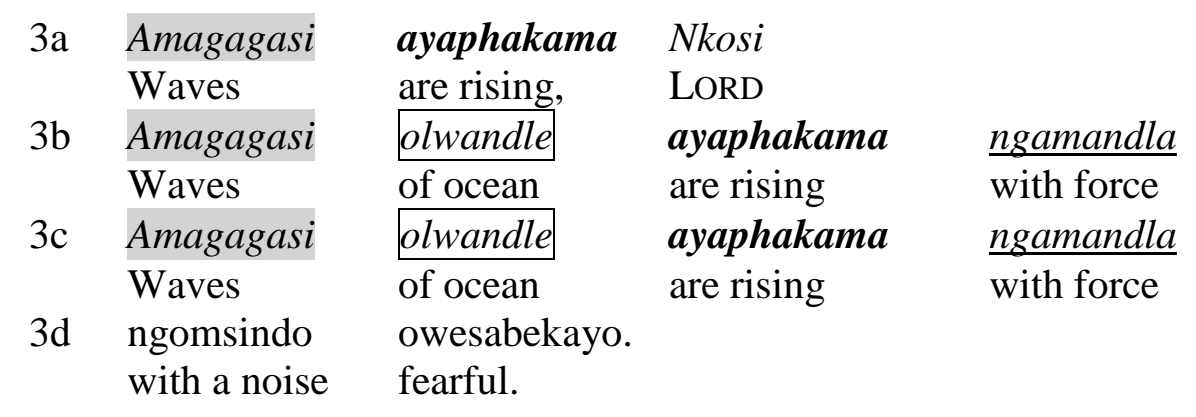

Another way in which rhetorical force was focussed on vv. 3-4 was by making these verses the chorus of the song, repeated several times in performance.

\section{2c Mnemonic Features}

Various poetic devices assist with memorisation: repetition of words (initiallinkage or tail-head linkage), repetition of sounds (assonance, alliteration, and rhyme), repetition of structures (parallelism), and a break in an established rhythm. Some examples of these different features follow:

(i) Initial-linkage and rhyme (of the last words of the cola)

1a uSimakade uyi Nkosi
The LORD is King
1b uSimakade ugcwele ubukhosi
The LORD (is) full of majesty
1c uSimakade wembethe amandla nobukhosi
The LORD (is) clothed with power and majesty


(ii) Tail-head linkage:

$$
\begin{array}{lll}
\text { 1b } & \text { Ngobukhosi } & \text { uvunule, } \\
& \text { With majesty } & \text { he is robed } \\
\text { 1c } & \text { uvunule } & \text { ubusomandla } \\
& \text { He is robed } & \text { with lordship }
\end{array}
$$

(iii) Intentional assonance and alliteration: ${ }^{71}$

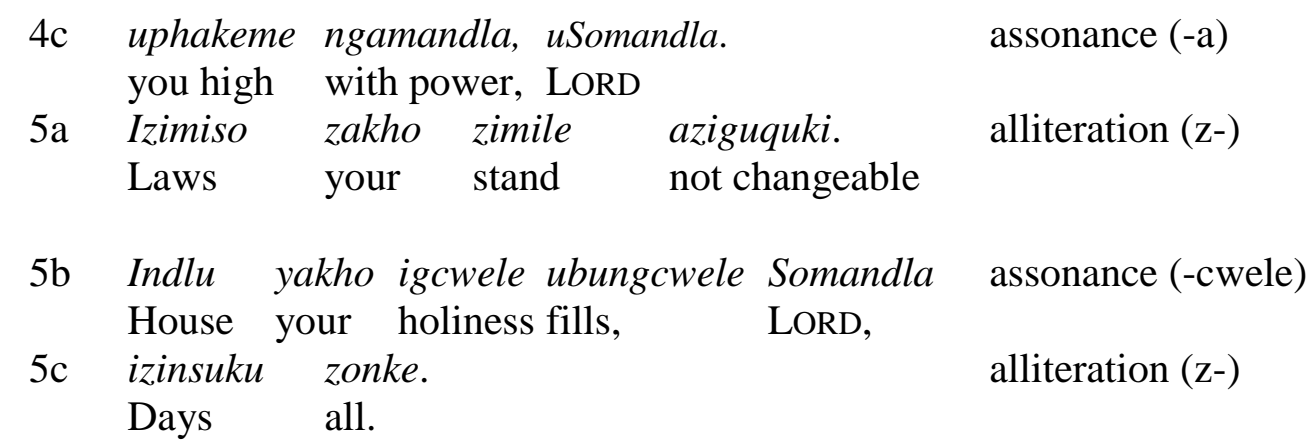

(iv) The use of an intensifier (Impela) and the use of parallelism (with positive repetition in 1d-1e and the repetition of the negation in 1e-1f):

1d Impela, umhlaba uqinile kakhulu;
Indeed, the earth firm very;
1e uqinile ungeguqulwe yilutho,
firm, can shake it nothing
1f. ungeguluqulwe yilutho.
can shake it nothing

(v) A break in the literary rhythm: in the example below, the first two cola ( $5 \mathrm{a}$ and $5 \mathrm{~b}$ ) both have 5 stressed syllables in the poetic line. To achieve this regular rhythm in $5 \mathrm{~b}$, a vocative is interjected. Then $5 \mathrm{c}$ breaks the rhythm with a short poetic line (just one word), thereby giving focus to the colon and making it memorable.

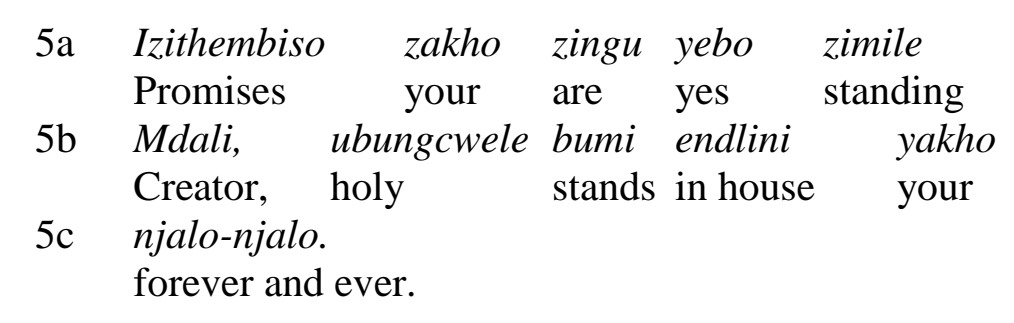

\section{2d Aesthetic Features}

Many of the same poetic features that facilitate memorisation are also aesthetically pleasing. For example, the use of alliteration, assonance, or a

\footnotetext{
71 Alliteration and assonance are common in isiZulu as a result of grammatical agreement.
} 
change in the length of the poetic line, not only add rhetorical force and mnemonic capacity, but also are "beautiful" to the listener.

The next example shows increasing length of the poetic line (from 3 a to $3 \mathrm{c})$, repetition of the verb $(3 \mathrm{x})$ and the topic $(2 \mathrm{x})$, intentional assonance of the a sound in all three cola, as well as a climactic, new word at the end of the last colon (viz. ngamandla). These features all provide significant aesthetic appeal to the listener.

3a Umoya uyavunguza,
The wind is blowing,
3b izivungu-vungu ziyavunguza,
the gales $\begin{aligned} & \text { are blowing, } \\ & \text { zc ivunguza ngamandla } \\ & \text { izivungu-vungu } \\ & \text { the gales }\end{aligned}$

The examples given above indicate the level of poetic artistry (and functionality achieved by the poetic devices) in the isiZulu translations. The next criterion of a literary-rhetorical text is aurality (enabling it to be heard and understood easily and remembered well). This feature is now briefly assessed in some of the empirical compositions.

\section{Criterion of Aurality}

For oral performance, the text must make use of features "that grab the ear." The aesthetic beauty, the mnemonic aids, and the rhetorical force must be heard. Many of the poetic devices already discussed are aurally-based (e.g. alliteration, assonance, rhyme, parallelism) but there are many other features that are typical of oral communication. ${ }^{72}$ One is rhythm, and this is used in various ways by oral communicators. In the empirical study, one group used rhythm as an introductory attention-getter to their song: for about two minutes, there was drumming, snapping of fingers, and the singing of a simple text Baba..., Mama... ("Father ..., Mother ..."). Many of the young people in the audience joined in and clearly enjoyed this typical Zulu feature of oral performance.

Another feature of aurality is the use of direct speech. It was interesting to see that some poets changed the 3rd person statements in v. 1 to direct address to the LORD, thereby adding a performative dimension of praise to his kingship, and highlighting his power.

$\begin{array}{ll}\text { 1b Ubukhosi } & \text { bungobakho } \\ \text { The majesty } & \text { is yours }\end{array}$

72 See June Dickie, "Zulu Song, Oral Art, Performing the Psalms to Stir the Heart," (PhD diss., University of KwaZulu-Natal, 2017), 36. http://researchspace.ukzn.ac.za /handle/10413/14223. 


$\begin{array}{lll}\text { 1c } & \text { Jehova, } & \text { uyingonyama } \\ \text { LORD, } & \text { you are the lion }\end{array}$

The remaining three criteria applied to the isiZulu translations are linked to the Zulu community and are discussed in the next section.

\section{Criteria of Naturalness, Clarity, and Acceptability}

With regard to the criteria of naturalness, clarity, and acceptability (or biblical authenticity), Reception Theory maintains that it is the audience who must draw the boundaries. Interviews with both the poets and audience members sought to assess how well the empirical performances rated on these criteria. Informal feedback during the performances was also noted.

Clapping, snapping of fingers, and ululating during the public performances indicated a very positive reception of the items by the Zulu audience. Interview responses (from both audience members and participants) were also positive, and many benefits were perceived..$^{73}$ In terms of naturalness and clarity, respondents indicated an appreciation for the message being clear and contextualised. Some comments were:

- "(The people) were able to understand in different ways God's word, using the singing and using drums."

- "(The Nguni people will enjoy having / creating more songs like these) because it is done in a way that people can relate to and understand better."

- "(Most people will enjoy singing the songs) because the translation used is much easier to understand than the original translation we have."

- "(What I liked best about the songs was) being able to translate the scripture into a song that I can relate to and understand, and be able to engage others as well."

With regard to assessing "biblical authenticity" or acceptability, some responses in the interviews indicated that the audience did consider what they were hearing to be "Scripture" and not just a Gospel song. One noted: "(People will enjoy singing the songs) because of the message and it still is part of the Scripture, not something we came up with." However, there is a need for further research to investigate this criterion more thoroughly. Clearly, the audience needs to be informed in order to be able to make a valid judgment. One way of doing this is to have translator-performers evaluate one another's work, possibly

73 The only real difficulty was for participants to be able to commit to the workshops for three consecutive Saturdays. Thus a variation could be to establish an online platform where community poets could learn, and share their translations and performances, in their own time and place. 
through an online platform where compositions and performances can be posted, and feedback welcomed.

Nevertheless, the empirical translations can be said to satisfy the six criteria of good literary-rhetorical translation of biblical poetry. On "accuracy," most of the poems captured the essential message. With regard to "artistry," most of the translations used various poetic features to achieve the emotive, rhetorical, aesthetic, and performative functions of the original text. "Aurality" was inherent in all the translations, the language was perceived as "natural" and "clear," and the audience accepted the "biblical authenticity" of the isiZulu text. By paying attention to not only the informative content of the Hebrew but also the emotive and rhetorical force, beautiful translations were achieved which satisfy the criteria of functional equivalence.

\section{E CONCLUSION}

It is frequently noted that the translation of poetry demands skill beyond that of the average translation team, but this study shows that interested, gifted volunteers can be trained relatively easily to enable them to produce creative translations which are aesthetically beautiful and rhetorically forceful. Although such translations may not serve as definitive translations for the whole community, the sense of ownership resulting from participation in the translation is a very significant benefit, as is the greater understanding of the text. Thus this methodology provides a systematic way of communicating the beauty and power of biblical poetry in indigenous languages such that the community owns the translation, is stirred by its poetics, and remembers the message. The three components of the methodology provide for translations that satisfy functional equivalence, incorporate the gifts of the community, and are rewarding to the participants and their audience.

\section{BIBLIOGRAPHY}

Bellinger, William H., Jr. Psalms: Reading and Studying the Book of Praises. Massachusetts: Hendrikson, 1990.

Bratcher, Robert G. and William D. Reyburn. A Translator's Handbook on The Book of Psalms. New York: United Bible Societies, 1991.

Briggs, Charles A. and Emilie G. Briggs. A Critical and Exegetical Commentary on the Book of Psalms. ICC. Edinburgh: T \& T Clark, 1960.

Brown, Duncan. Voicing the Text: South African Oral Poetry and Performance. Cape Town: Oxford University Press, 1998.

Brown, Francis, S. R. Driver, and Charles A. Briggs. Hebrew-English Lexicon, incorporated in Translators Workplace. SIL and UBS, 2008.

Brueggemann, Walter and William H. Bellinger. Psalms. New York: CUP, 2014.

Bullock, C. Hassel. Encountering the Book of Psalms. Grand Rapids: Baker Books, 2001.

Dahood, Mitchell, S. J. Psalms II (51-100). AB. New York: Doubleday, 1968. 
DeClaisse-Walford, Nancy, Rolf A. Jacobson, and Beth LaNeel Tanner. Overview of the Shape and Shaping of the Book of Psalms: The Current State of Scholarship. Atlanta: SBL Press, 2014.

Dickie, June F. "Zulu Song, Oral Art, Performing the Psalms to Stir the Heart." Ph.D Diss., University of KwaZulu-Natal, 2017. http://researchspace.ukzn.ac.za /handle/10413/14223.

Gerstenberger, Erhard S. Psalms, Part 2 and Lamentations. Grand Rapids: Eerdmans, 2001.

Gunner, Elizabeth. "Wand or Walking Stick? The Formula and its Use in Zulu Praise Poems." Pages 185-207 in The Oral Performance in Africa. Edited by Isidore Okpewho. Nigeria: Spectrum Books Ltd, 1990.

Harris, R. Laird, Gleason L. Archer Jr, and Bruce K. Waltke eds. Theological Wordbook of the Old Testament. NavPress Software incorporated in Translators Workplace. SIL and UBS, 2008.

Hossfeld, Frank-Lothar and Erich Zenger. Psalms. Vol. 2. Minneapolis: Fortress Press, 2005.

Howard, David M. "Recent Trends in Psalms Study." Pages 1-32 in The Face of Old Testament Studies. Edited by David W. Baker and Bill T. Arnold. Grand Rapids: Baker Books, 1999.

Irsigler, Hubert. “Thronbesteigung in Ps 93?” Pages 155-190 in Text, Methode und Grammatik: FS W. Richter. Edited by Walter Gross, Hubert Irsingler, and Theodor Seidl. St Ottilien: EOS, 1991.

Kirkpatrick, Alexander F. The Book of Psalms. Cambridge: CUP, 1902.

Krauss, Hans-Joachim. Psalms 60-150. Minneapolis: Augsburg, 1989.

McCann, J. Clinton. The Shape and Shaping of the Psalter. JSOTSup 159. Sheffield: JSOT Press, 1993.

Mowinckel, Sigmund O. P. The Psalms in Israel's Worship. Oxford: Basil Blackwell, 1982.

Nida, Eugene A. Towards a Science of Translating: With Special Reference to Principles and Procedures Involved in Bible Translating. Leiden: Brill, 1964.

Peterson, Eugene H. Where your Treasure Is. Grand Rapids: Eerdmans, 1993.

Shenkel, James D. "The Dead Sea Psalms Scroll." Bib 46 (1965): 413.

Tate, Marvin. Psalms 51-100. Dallas, TX: Word Books, 1990.

Wendland, Ernst R. Translating the Literature of Scripture. Dallas: SIL, 2004.

Westermann, Claus. The Living Psalms. Grand Rapids: Eerdmans, 1984.

Willis, John T. "The Juxtaposition of Synonymous and Chiastic Parallelism in Tricola in Old Testament Hebrew Psalm Poetry." VT 29/4 (1979): 465-480.

Zakovitch, Yair. "The Interpretive Significance of the Sequence of Psalms." Pages 215-228 in The Composition of the Book of Psalms. Edited by Erich Zenger. Leuven: Uitgeverij Peeters, 2010.

June Dickie, 26 Mills Circle, Hayfields, Pietermartizburg 3201. E-mail: junedickie@gmail.com. 